\title{
Evaluation of hearing status in patients with keratoconus: A case-control study
}

\section{Keratokonuslu hastalarda işitme durumunun değerlendirilmesi: Bir olgu-kontrol çalışması}

\author{
Mustafa Çelik (1), Erdinç Bozkurt (1) \\ ${ }^{1}$ Department of Otolaryngology, Kafkas University Faculty of Medicine, Kars, Turkey \\ ${ }^{2}$ Department of Ophthalmology, Kafkas University, Faculty of Medicine, Kars, Turkey
}

\section{ABSTRACT}

Objectives: This study aims to evaluate the hearing status of patients with keratoconus.

Patients and Methods: This case-control study, conducted between November 2018 and April 2019, included 56 subjects (25 males, 31 females; mean age $31.2 \pm 7.5$ years; range, 18 to 49 years) 23 of whom (12 males, 11 females; mean age 31.6 \pm 7.8 years, 20 to 46 years) were diagnosed with keratoconus while 33 (13 males, 20 females; mean age $30.8 \pm 4.4$ years; range, 18 to 49 years) had no eye disease (control group). Pure tone audiometry, immitansmetric measurements, and auditory brainstem response tests were performed in all patients. Audiological test results of the groups were compared.

Results: There was no statistically significant difference between the age and gender distribution of the groups $(\mathrm{p}=0.336$ and $\mathrm{p}=0.125$, respectively). In the control group, the acoustic reflex value of $2,000 \mathrm{~Hz}$ was significantly higher than the keratoconus group $(\mathrm{p}=0.030 ; \mathrm{p}<0.05)$. There was no significant difference in the other acoustic reflex measurements of the groups (all $p$ values $>0.05$ ). There was no statistically significant difference between the I-III, III-V, and I-V wave latencies in the auditory brainstem response test measurements (all $p$ values $>0.05$ ).

Conclusion: According to the results of this study, hearing loss is not expected in patients with keratoconus. Therefore, we believe that there is no need for a routine hearing examination in such patients. Long-term follow-up studies with larger sample sizes are needed.

Keywords: Acoustic reflex, auditory brainstem response, hearing, keratoconus, tympanic membrane.
$\ddot{O} Z$

Amaç: Bu çalışmada keratokonuslu hastaların işitme durumu değerlendirildi.

Hastalar ve Yöntemler: Kasım 2018-Nisan 2019 tarihleri arasında gerçekleştirilen bu olgu-kontrol çalışmasına 23' ü (12 erkek, 11 kadın; ort. yaş 31.6 \pm 7.8 yıl; dağılım, 20-46 yıl) keratokonus tanısı almışken 33'ünde (13 erkek, 20 kadın; ort yaş $30.8 \pm 4.4$ yıl; dağılım, 18-49 yıl) hiçbir göz hastalığı olmayan (kontrol grubu) 56 denek (25 erkek, 31 kadın; ort. yaş 31.2 \pm 7.5 yıl; dağılım, 18-49 yıl) dahil edildi. Tüm hastalarda saf ses odyometrisi, immitansmetrik ölçümler ve işitsel beyin sapı yanıtı testleri uygulandı. Grupların odyolojik test sonuçları karşılaştırıldı.

Bulgular: Grupların yaş ve cinsiyet dağılımı arasında istatistiksel olarak anlaml 1 farklılık yoktu (sırasıyla, $\mathrm{p}=0.336$ ve $\mathrm{p}=0.125$ ). Kontrol grubunda $2000 \mathrm{~Hz}$ ' deki akustik refleks değeri keratokonus grubundan anlamlı şekilde yüksekti $(\mathrm{p}=0.030$; $\mathrm{p}<0.05$ ). Grupların diğer akustik refleks ölçümlerinde anlamlı farklılık yoktu (tüm $p$ değerleri $>0.05$ ). İşitsel beyin sapı yanıtı testi ölçümlerinde I-III, III-V ve I-V dalga gecikmeleri arasında istatistiksel olarak anlamlı farklılık yoktu (tüm $p$ değerleri $>0.05)$.

Sonuç: $\mathrm{Bu}$ çalışmanın sonuçlarına göre, keratokonuslu hastalarda işitme kaybı beklenmemektedir. Dolayısıyla, bu hastalarda rutin işitme muayenesine gerek olmadiğına inanıyoruz. Daha büyük örneklem boyutları olan, uzun süreli takip çalışmaları gereklidir.

Anahtar sözcükler: Akustik refleks, işitsel beyin sapı yanıtı, işitme, keratokonus, kulak zarı.

Received: March 03, 2020 Accepted: March 28, 2020 Published online: June 11, 2020

Correspondence: Mustafa Çelik, MD. Beykent Üniversitesi Tip Fakültesi Kulak Burun Boğaz Anabilim Dalı, 34100 Büyükçekmece, İstanbul, Türkiye. e-mail:dr.mcelik@yahoo.com 
Keratoconus is a non-inflammatory chronic ectatic condition presenting with insidious onset, often increasing myopia and loss of vision due to irregular astigmatism. ${ }^{[1,2]}$ Although its prevalence varies from country to country, it has been reported to be $50-2,300 / 100,000 \cdot \cdot^{[3-5]}$ It generally affects the age group of 18-40 years, and if not treated, leads to deterioration in the quality of life. ${ }^{[1,4]}$

Although there are many studies on the etiopathology of keratoconus in the literature, its etiopathology has not been fully elucidated. The current literature data show that the relationship between keratoconus and systemic diseases has been investigated..$^{[6-9]}$ Understanding the relationship between systemic diseases and keratoconus may contribute to understanding the pathology of the disease. Ocular allergy, atopy, connective tissue diseases, and Down syndrome were reported as predisposing factors for keratoconus in the Global Delphi Panel of Keratoconus and Ectatic Diseases in 2015 , according to a survey conducted with panelists after the meeting. ${ }^{[4]}$ Studies have shown that collagen vascular diseases, aortic aneurysm, and sleep apnea are also associated with keratoconus. ${ }^{[8,10,11]}$ Furthermore, considering the role of the immune system in the pathogenesis of keratoconus, the relationship between autoimmune diseases and keratoconus was investigated and keratoconus prevalence was found to be higher in autoimmune diseases such as rheumatoid arthritis and Hashimoto thyroiditis. ${ }^{[12-14]}$

Sensorineural hearing loss has been associated with various diseases and syndromes, and it has been reported that sensorineural hearing loss is more common in autoimmune diseases, collagen tissue diseases, and vascular pathologies. ${ }^{[15-17]}$ Considering the common etiological factors, hearing loss may occur in keratoconus patients. To our knowledge, there are no studies evaluating hearing status in keratoconus patients in the literature. Therefore, in this study, we aimed to evaluate the hearing status of patients with keratoconus.

\section{PATIENTS AND METHODS}

This case-control study was conducted between November 2018 and April 2019 by the department of the otorhinolaryngology and the ophthalmology of Kafkas University Training and Research Hospital. The study protocol was approved by the Kafkas University Training and Research Hospital Ethics Committee (number and date: 80576354-050-99/18231.10.2018). A written informed consent was obtained from each participant. The study was conducted in accordance with the Guidelines for Good Clinical
Practice and the principles of the Declaration of Helsinki.

The study included 56 subjects (25 males, 31 females; mean age $31.2 \pm 7.5$ years; range 18 to 49 years) 23 of whom (12 males, 11 females; mean age $31.6 \pm 7.8$ years, 20 to 46 years) were diagnosed with keratoconus stage 2 and above according to AmslerKrumeich classification ${ }^{[18]}$ while 33 (13 males, 20 females; mean age $30.8 \pm 4$. 4 years; range 18 to 49 years) had normal hearing and had no eye or systemic disease (control group).

Subjects older than 18 years with normal otorhinolaryngologic examination and type A tympanogram were included. Subjects with external or middle ear pathology, acoustic trauma, ototoxicity, family history of hearing loss, otologic surgery or head trauma were excluded. All subjects included in the study underwent complete otorhinolaryngologic examination.

Corneal topography device (Sirius imaging system, Costruzioni Strumenti Oftalmici, Florence, Italy) and keratometry values (K1, K2), corneal thickness map and pachymetric measurement of the thinnest part of the cornea anterior chamber depth, anterior chamber angle, and corneal volumes were measured.

Sample size was calculated according to the estimated sample size formula for cross-sectional studies. ${ }^{[19]}$ Standard effect size was determined as 0.92 with $5 \%$ error rate, $80 \%$ power. At least 22 ears (11 cases) were sufficient for each group.

Pure tone audiometry, immitansmetric measurements, and auditory brainstem response (ABR) tests were performed in all cases. Pure tone air and bone conduction hearing thresholds (right/left ear) were determined by clinical audiometry (Interacoustics AC40, Assens, Denmark) in quiet rooms of the Industrial Acoustics Company standard. Airway pure tone hearing thresholds were measured in the range of $125-6,000 \mathrm{~Hz}$, while high frequency hearing thresholds were measured in the range of 8,000-16,000 $\mathrm{Hz}$. Bone pathway conduction thresholds were evaluated in the range of $500-4,000 \mathrm{~Hz}$. In immitansmetric measurements, $226 \mathrm{~Hz}$ probe tone (Interacoustics AZ26, Assens, Denmark) was used and middle ear pressure of all subjects (right/left ear) was measured for ipsilateral and contralateral acoustic reflex thresholds at 500, 1,000, 2,000, and 4,000 Hz. Subjects with type A tympanogram at -100 to +50 dekapascal pressure were included in the study. The ABR test was performed in the natural supine position without sedation. The active electrode was placed on the forehead, the passive electrode on the ear-side mastoid projection where the 


\begin{tabular}{|c|c|c|c|}
\hline \multicolumn{4}{|c|}{$\begin{array}{c}\text { Table 1 } \\
\text { Corneal topographic values of keratoconus and healthy eyes }\end{array}$} \\
\hline & Keratoconus eye $(n=46)$ & Healthy eye $(n=66)$ & \\
\hline & Mean \pm SD & Mean \pm SD & $p^{*}$ \\
\hline K1 (D) & $46.3 \pm 2.5$ & $43.2 \pm 1.8$ & $<0.01$ \\
\hline $\mathrm{K} 2$ (D) & $50.7 \pm 3.1$ & $44.3 \pm 1.4$ & $<0.01$ \\
\hline The thinner of cornea $(\mu \mathrm{m})$ & $417.3 \pm 41.9$ & $544.9 \pm 31.5$ & $<0.01$ \\
\hline Corneal volume $\left(\mathrm{mm}^{3}\right)$ & $51.2 \pm 3.7$ & $52.1 \pm 3.9$ & 0.191 \\
\hline Anterior chamber depth (mm) & $3.4 \pm 0.2$ & $3.1 \pm 0.3$ & $<0.01$ \\
\hline Iridocorneal angle $\left({ }^{\circ}\right)$ & $49.2 \pm 3.3$ & $48.1 \pm 4.1$ & 0.194 \\
\hline
\end{tabular}

stimulus was given, and the earth electrode was placed on the opposite mastoid projection. Absolute latencies of I, III and V waves calculated at waveform obtained at $85 \mathrm{~dB} \mathrm{nHL}$ as well as latency values between I-III, III-V and I-V waves were recorded. Transient evoked otoacoustic emissions and distortion product otoacoustic emissions tests could not be performed because there was no otoacoustic emission measurement device in our hospital. Audiological test results of the groups were compared.

\section{Statistical analysis}

The Number Cruncher Statistical Systems 2007 (Kaysville, Utah, USA) software was used for statistical analysis. While evaluating the study data, descriptive statistics of mean, standard deviation, median, frequency, ratio, minimum, and maximum were used. Mann-Whitney $U$ test was used for the analysis of quantitative independent data. Chi-square test was used for the analysis of qualitative independent data. Statistical significance was accepted as $\mathrm{p}<0.05$.

\section{RESULTS}

Demographic characteristics of the groups are given in Table 1. There was no statistically significant difference between age and gender distribution of the groups $(p=0.336$ and $p=0.125$, respectively). The comparison of pure tone audiometry results of the groups is summarized in Table 2. In the control group, the acoustic reflex value of $2,000 \mathrm{~Hz}$ was significantly higher than the keratoconus group $(p=0.030 ; p<0.05)$. There was no significant difference in the other acoustic reflex measurements of the groups (all $p$ values $>0.05$ ) (Table 3 ). There was no statistically significant difference between the I-III, III-V, and $\mathrm{I}-\mathrm{V}$ wave latencies in the $\mathrm{ABR}$ test measurements (all $p$ values $>0.05$ ) (Table 4).

\section{DISCUSSION}

Although keratoconus has been shown to be associated with many diseases and pathologies, it is a situation often seen alone. Systemic pathologies that may be observed in patients with keratoconus are still being investigated. Demonstrating the relationship between different systemic diseases and keratoconus

Table 2

Comparison of pure tone audiometry results of groups

\begin{tabular}{|c|c|c|c|}
\hline & Keratoconus group & Control group & \\
\hline $\mathrm{Hz}$ & Mean \pm SD & Mean \pm SD & $p^{*}$ \\
\hline Air 250 & $14.3 \pm 6.4$ & $12.1 \pm 5.9$ & 0.040 \\
\hline Air 500 & $11.4 \pm 6.2$ & $10.9 \pm 6.1$ & 0.589 \\
\hline Air 1,000 & $10.0 \pm 5.5$ & $9.1 \pm 5.5$ & 0.652 \\
\hline Air 2,000 & $10.9 \pm 7.5$ & $9.7 \pm 6.0$ & 0.700 \\
\hline Air 4,000 & $13.4 \pm 9.6$ & $11.9 \pm 8.5$ & 0.402 \\
\hline Air 6,000 & $12.5 \pm 7.2$ & $16.0 \pm 13.1$ & 0.703 \\
\hline Air 8,000 & $11.1 \pm 5.5$ & $16.9 \pm 11.4$ & 0.000 \\
\hline Air 9,000 & $12.1 \pm 8.8$ & $14.7 \pm 15.5$ & 0.477 \\
\hline Air 10,000 & $11.5 \pm 10.5$ & $13.1 \pm 11.6$ & 0.289 \\
\hline Air 11,200 & $11.7 \pm 1$ & $15.9 \pm 16.6$ & 0.119 \\
\hline Air 12,500 & $16.1 \pm 16.2$ & $17.6 \pm 16.1$ & 0.157 \\
\hline Air 14,000 & $22.0 \pm 17.7$ & $21.2 \pm 17.0$ & 0.545 \\
\hline Air 16,000 & $36.0 \pm 21.0$ & $26.7 \pm 19.7$ & 0.059 \\
\hline Bone 500 & $8.7 \pm 4$ & $8.2 \pm 3.7$ & 0.346 \\
\hline Bone 1,000 & $7.8 \pm 3.6$ & $7.8 \pm 3.8$ & 0.692 \\
\hline Bone 2,000 & $8.7 \pm 4.8$ & $8.4 \pm 4.2$ & 0.922 \\
\hline Bone 4,000 & $10.8 \pm 8.2$ & $9.1 \pm 6.7$ & 0.327 \\
\hline
\end{tabular}




\begin{tabular}{|c|c|c|c|}
\hline \multicolumn{4}{|c|}{$\begin{array}{c}\text { Table } 3 \\
\text { Evaluation of acoustic reflex measurements according to groups }\end{array}$} \\
\hline & Keratoconus group & Control group & \\
\hline $\mathrm{Hz}$ & Mean \pm SD & Mean \pm SD & $p^{*}$ \\
\hline Ipsilateral 500 & $88.2 \pm 4.6$ & $87.7 \pm 4.5$ & 0.399 \\
\hline Ipsilateral 1,000 & $87.8 \pm 4.2$ & $88.3 \pm 4.2$ & 0.553 \\
\hline Ipsilateral 2,000 & $88.6 \pm 4.0$ & $88.9 \pm 4.22$ & 0.826 \\
\hline Contralateral 500 & $87.4 \pm 4.1$ & $88.1 \pm 4.6$ & 0.792 \\
\hline Contralateral 1,000 & $89.1 \pm 4.3$ & $89.6 \pm 4.2$ & 0.526 \\
\hline Contralateral 2,000 & $88.4 \pm 4.4$ & $90.2 \pm 4.6$ & 0.030 \\
\hline Contralateral 4,000 & $88.9 \pm 4.7$ & $90.7 \pm 4.9$ & 0.510 \\
\hline
\end{tabular}

will contribute to a better understanding of the pathogenesis of keratoconus and provide early diagnosis and treatment while preventing the development of possible complications.

While the relationship between many eye diseases and hearing status has been investigated, ${ }^{[20-22]}$ to our knowledge, no study has evaluated hearing in patients with keratoconus. In this study, hearing levels were evaluated in keratoconus patients. Pure tone audiometry, acoustic reflex, and ABR tests were performed. No statistically significant difference was seen in hearing levels between control and keratoconus subjects. Thus this case-control study is the first to evaluate hearing levels in keratoconus patients in the literature.

The current literature shows that corneal collagen tissue defects play a role in the development of keratoconus. It has been shown that cross-link abnormalities between corneal collagen facilitate the development of keratoconus. ${ }^{[23]}$ Corneal stroma contains mainly type 1 ,

\begin{tabular}{|c|c|c|c|}
\hline \multicolumn{4}{|c|}{$\begin{array}{c}\text { Table } 4 \\
\text { Evaluation of inter-wave latencies in auditory } \\
\text { brainstem response by groups }\end{array}$} \\
\hline & Keratoconus group & Control group & \\
\hline & Mean \pm SD & Mean \pm SD & $p^{*}$ \\
\hline $\mathrm{I}$ & $1.5 \pm 0.9$ & $1.5 \pm 0.1$ & 0.578 \\
\hline III & $3.7 \pm 0.2$ & $3.7 \pm 0.2$ & 0.588 \\
\hline $\mathrm{V}$ & $5.5 \pm 0.3$ & $5.5 \pm 0.3$ & 0.548 \\
\hline I-III & $2.2 \pm 0.1$ & $2.1 \pm 0.2$ & 0.918 \\
\hline $\mathrm{I}-\mathrm{V}$ & $4.0 \pm 0.3$ & $4.0 \pm 0.3$ & 0.789 \\
\hline III-V & $1.8 \pm 0.3$ & $1.8 \pm 0.3$ & 0.334 \\
\hline
\end{tabular}

type 3 , and type 5 collagen. ${ }^{[24]}$ Like the corneal stroma, the tympanic membrane contains type 1 and type 5 collagen. ${ }^{[25]}$ If kerotoconus disease is due to systemic collagen tissue defect, various abnormalities would be expected in the tympanic membrane containing type 1 and type 5 collagen. Along with structural and functional changes in the tympanic membrane, retraction pockets in the tympanic membrane, atelectasis, and tympanic membrane perforations result in various types of hearing loss, particularly conductive hearing loss. However, no abnormalities were observed in the tympanic membrane of patients with keratoconus. Also, no abnormality was detected in immitansmetric measurements in these patients. These data show that collagen tissue defect in keratoconus cases is not systemic and localized at corneal level.

Acoustic reflex measurements in afferent and efferent stimuli VIII. nerve (N. Cochlearis), VII. nerve (nervus facialis) and related regions are examined. According to the results of ipsilateral and contralateral acoustic reflex of both ears, information about lesion locations and their effects on hearing can be obtained. ${ }^{[26]}$ In this study, no statistically significant difference was observed between keratoconus and healthy subjects in acoustic reflex evaluation. This shows that no pathological changes have been observed in the anatomical structures of the acoustic reflex pathway.

The ABR wave amplitudes and latency differences between waves may provide information about pathologies in central auditory pathways. ${ }^{[27]}$ In our study, there was no difference in the amplitude of ABR waves and latency between waves in keratoconus grup compared to control group and no abnormality was detected in waves. This shows that there is no effect on cochlear and retrocochlear hearing pathways in patients with keratoconus. 
This is a valuable study because it is the first to evaluate hearing in patients with keratoconus. Another strength of the study is the use of the ABR test which provides information about central hearing pathways. Power analysis was performed in this study and a sufficient number of cases were included. Still, we think that further studies with larger sample sizes will add more value. In this study, no sensorineural hearing loss was observed in patients with keratoconus. No abnormalities were detected in the central auditory tracts. Based on the data of this study, we believe that there is no need for a routine hearing assessment in patients with keratoconus. In keratoconus patients, additional examination to evaluate hearing levels may cause unnecessary financial burden unless there is a complaint of hearing loss.

Although this study contains important data about the hearing status of keratoconus patients, there are some limitations. The relatively low number of subjects and the evaluation of hearing levels of keratoconus patients at diagnosis are the main limitations. Long-term follow-up of keratoconus patients could have provided healthier results. In addition, the inability to measure otoacoustic emissions demonstrating cochlear effect (external hairy cell effect) can be considered as another limitation.

In conclusion, according to the results of this study, hearing loss is not expected in patients with keratoconus and we believe that there is no need for a routine hearing examination in such patients. However, long-term follow-up studies with larger sample sizes are needed on this subject.

\section{Declaration of conflicting interests}

The authors declared no conflicts of interest with respect to the authorship and/or publication of this article.

\section{Funding}

The authors received no financial support for the research and/or authorship of this article.

\section{REFERENCES}

1. Woodward MA, Blachley TS, Stein JD. The association between sociodemographic factors, common systemic diseases, and keratoconus: an analysis of a nationwide heath care claims database. Ophthalmology 2016;123:457-65.

2. Jonas JB, Nangia V, Matin A, Kulkarni M, Bhojwani K. Prevalence and associations of keratoconus in rural maharashtra in central India: the central India eye and medical study. Am J Ophthalmol 2009;148:760-5.

3. Krachmer JH, Mannis MJ, Holland EJ, editors. Cornea. Mosby: Elsevier; 2011.
4. Gomes JA, Tan D, Rapuano CJ, Belin MW, Ambrósio R Jr, Guell JL, et al. Global consensus on keratoconus and ectatic diseases. Cornea 2015;34:359-69.

5. Zhao F, Du F, Zhang J, Xu J. Trends in Research Related to Keratoconus From 2009 to 2018: A Bibliometric and Knowledge Mapping Analysis. Cornea 2019;38:847-54.

6. Kosker M, Suri K, Hammersmith KM, Nassef AH, Nagra PK, Rapuano CJ. Another look at the association between diabetes and keratoconus. Cornea 2014;33:774-9.

7. Kosker M, Arslan N, Alp MY, Ozisler C, Acar M, Dogan AS, et al. Association Between Keratoconus and Familial Mediterranean Fever in Turkey. Cornea 2016;35:77-80.

8. Skorin L Jr, Knutson R. Ophthalmic diseases in patients with obstructive sleep apnea. J Am Osteopath Assoc 2016;116:522-9.

9. Bawazeer AM, Hodge WG, Lorimer B. Atopy and keratoconus: a multivariate analysis. $\mathrm{Br} \mathrm{J}$ Ophthalmol 2000;84:834-6.

10. Kalkan Akcay E, Akcay M, Uysal BS, Kosekahya P, Aslan AN, Caglayan M, et al. Impaired corneal biomechanical properties and the prevalence of keratoconus in mitral valve prolapse. J Ophthalmol 2014;2014:402193.

11. Sargazi S, Moudi M, Heidari Nia M, Saravani R, Malek Raisi H. Association of KIF26B and COL4A4 gene polymorphisms with the risk of keratoconus in a sample of Iranian population. Int Ophthalmol 2019;39:2621-8.

12. Nemet AY, Vinker S, Bahar I, Kaiserman I. The association of keratoconus with immune disorders. Cornea 2010;29:1261-4.

13. Lee R, El-Massry A, El-Massry Y, Randleman JB. Bilateral, Asymmetric Keratoconus Induced by Thyrotoxicosis With Long-term Stability After Corneal Cross-linking. J Refract Surg 2018;34:354-6.

14. Kim J, Netto MV. Keratoconus associated with hyperimmunoglobulin E syndrome. Cornea 2004;23:93-6.

15. Akdag M, Uçmak D, Özkurt FE, Bozkurt M, Akkurt ZM, Topçu İ. Evaluation of Hearing and Outer Hair Cell Function of Cochlea in Patients With Psoriatic Arthritis. Clin Exp Otorhinolaryngol 2015;8:183-8.

16. Sonbay ND, Saka C, Tatlican S, Vuralkan E, Aygener N, Eren C, Akin I. Audiological evaluation in patients with Behçet's disease. J Laryngol Otol 2014;128:694-7.

17. Ralli M, Altissimi G, Di Stadio A, Mazzei F, Turchetta R, Cianfrone G. Relationship between hearing function and myasthenia gravis: A contemporary review. J Int Med Res 2017;45:1459-65.

18. Krumeich JH, Kezirian GM. Circular keratotomy to reduce astigmatism and improve vision in stage I and II keratoconus. J Refract Surg 2009;25:357-65.

19. Kelsey JL, Jhittemore AS, Evans AS, Thompson WD. Methods of sampling and estimation of sample size. In: Kelsey JL, Jhittemore AS, Evans AS, Thompson WD, editors. Methods in Observational Epidemiology. $2^{\text {nd }}$ ed. New York: Oxford University Press; 1996. p. 311-40

20. Temporale H, Karasińska-Kłodowska A, Turno-Kręcicka A, Morawska-Kochman M, Dorobisz K, Dudek Ket al. Evaluating the Hearing of Patients with Pseudoexfoliation Syndrome. Adv Clin Exp Med 2016;25:1215-21. 
21. Batson S, Kelly K, Morrison D, Virgin F. Ophthalmologic Abnormalities in Children with Congenital Sensorineural Hearing Loss. J Binocul Vis Ocul Motil 2019;69:126-30.

22. Mathur PD, Yang J. Usher syndrome and non-syndromic deafness: Functions of different whirlin isoforms in the cochlea, vestibular organs, and retina. Hear Res 2019;375:14-24.

23. Kok YO, Tan GF, Loon SC. Review: keratoconus in Asia. Cornea 2012;31:581-93.

24. Marshall GE, Konstas AG, Lee WR. Immunogold fine structural localization of extracellular matrix components in aged human cornea. II. Collagen types $\mathrm{V}$ and VI.
Graefes Arch Clin Exp Ophthalmol 1991;229:164-71.

25. Knutsson J, Bagger-Sjöbäck D, von Unge M. Collagen type distribution in the healthy human tympanic membrane. Otol Neurotol 2009;30:1225-9.

26. Ünsal S, Karataş H, Kaya M, Gümüş NM, Temügan E, Yüksel M, et al. Evaluation of Acoustic Reflex and Reflex Decay Tests in Geriatric Group. Turk Arch Otorhinolaryngol 2016;54:10-5.

27. Abd El-Ghaffar NM, El-Gharib AM, Kolkaila EA, Elmahallawy TH. Speech-evoked auditory brainstem response with ipsilateral noise in adults with unilateral hearing loss. Acta Otolaryngol 2018;138:145-52. 